\title{
Empirical Investigations into Macroeconomic Variables and Internal Remittances in Rural Ghana
}

\author{
Nicholas Awuse (Corresponding author) \\ Bolgatanga Polytechnic \\ P. O. Box 767, Sumbrungu, Bolgatanga, Ghana
}

Tel: 233-243-924-839_E-mail: akaare2002@yahoo.com

\author{
Patrick Tandoh-Offin \\ Ghana Institute of Management and Public Administration (GIMPA) \\ P. O. Box AH-50, Achimota-Accra, Ghana \\ Tel: 233-247-450-433 E-mail:ptandoh@gimpa.edu.gh
}

\begin{abstract}
Received: December 20, 2013 Accepted: January 16, $2014 \quad$ Published: May 28, 2014
doi:10.5296/ijssr.v2i2.4772 URL: http://dx.doi.org/10.5296/ijssr.v2i2.4772
\end{abstract}

\begin{abstract}
This study examines the link between macroeconomic indicators of workers' (formal and informal) and remittances in Rural Ghana. A number of regressions tests have been conducted and found the link between price increases, cost of borrowing in Ghana and the remittances. According to the available statistics, remittances in Ghana do not have any significant impact on the macroeconomic variables.

This particular study indicated that in Ghana, if the gross domestic product popularly called GDP, increases, other things being equal, local inflows into the regions falls by $-0.003 \%$. It follows from this study, if the GDP rate in Ghana goes up, domestic interest rate decreases by $-0.98 \%$. Again, if the GDP increases by $1 \%$ change, inflation rate of Ghana falls significantly by $-0.060 \%$. In conclusion, local inflows into various regions do not react to the changes in domestic interest. From this study, remittances do not contribute significantly to the growth of this economy.
\end{abstract}

Keywords: macroeconomics, remittances, inflation, GDP, domestic interest rate, Ghana 


\section{Introduction}

Of late, internal migration and poverty reduction are used often and considerably to mean internal migrants looking for better economic opportunities within the country and to escape from poverty and food insecurity, tribal wars and low agricultural yields which has come as a result of climatic changes globally. Internal remittances have become a major source of livelihood for many households in both rural and urban areas in Ghana. Every year, a large number of active labour forces are moving round the country and sending remittances to their relatives' home and elsewhere which is one of the major sources of their income.

This study is troubled about the time series econometric analysis of the determinant of remittance inflow into regions and Districts in Ghana. However, (Department of Labour, under the Ministry of Employment and Social Welfare and Ghana Statistical Service) have official records on the statistics of labour workers and their remittances in Ghana. It was the intention of this study to provide reliable and accurate data for our understanding of the phenomenon. The variables used are domestic inflation rate, domestic interest rate and the weighted average of Gross Domestic Product (GDP) of the Ghana. The question many of us asked is: Is this situation or picture peculiar to only Ghana or it exist elsewhere in the world? The answer to this question can be found in literature of this study below.

\section{Literature Review}

This study has reviewed literature related to macroeconomic determinants and their influence on internal inflows into the various regions of Ghana. In general, this study discusses the relationship between macroeconomic variables such as inflation, domestic interest rate and Gross Domestic Product growth rate in Ghana and includes their effects and outcome of this inclusion, then literature relating to macroeconomic variables and their association with internal remittances and finally how macroeconomic indicators and internal remittance behave in Ghana. Some researchers attribute the behaviour or interaction among macroeconomic indicators and internal remittances to have significant impact on them while some variables do not have significant influence on them.

According to a research conducted in Egypt by Elsakka and Mcnabb (1999) about internal remittances and macroeconomic variables such as inflation, domestic interest rate and real economic growth rate, it was found that black market premium have significant contribution on domestic interest rate. In another research by Katseli and Glyson (1986) in Greece, internal remittances disclosed a negative relationship among inflation, interest rate, GDP growth rate and interest rate. These findings are in conformity with this study which shown a similar pattern in Ghana.

The analysis above indicates that the study seeks to revise and extend knowledge in the understanding of the concept internal remittances and their relationships with the macroeconomic variables in Ghana.

From the above literature, let us see how our data related to this study was collected and analysed to arrive at conclusion and why this particular technique was used. 


\section{Research Methodology}

\subsection{Introduction}

In our regression analysis we have taken time series data and log-linear functional form. The data used in our analysis are taken from the Ghana Statistical Services from $1992-2011$ and other sources. After operating regression analysis in software Stata and also Sas, we had the result of the study. The methodology of the study looks at the technique of data collection and how we analysis our results.

\subsection{Specification of Model}

Following econometric results, we used log- linear forms of regression for the convenience. The superiority of the Log -Linear model is that the coefficients of the variable measure the elasticity of regressand with respect to regressors.

Here the parameters b, c, d, and e will show the elasticity of the regressand with respect to the regressors respectively.

GDPWt $=9.725-0.060$ INFDt -0.099 INTRDt -0.003 REMt

Taking $\log$ - linear form

$\mathrm{REM}=$ Remittances inflow into the regions

$\mathrm{INFD}=$ Domestic inflation rate

$\mathrm{INTRDR}=$ Domestic rate of interest

GDPW = Simple Average of GDP (dependent variable)

$\mathrm{A}=$ Represent a constant term or the intercept

If the inflation rate of Ghana increases, it will show the negative effect on remittance inflow to their areas of origin. Again there is a positive response on the remittance inflow if the interest rate of Ghana increases relatively than other regions.

\subsection{Estimation of the Model}

\subsubsection{Testing Unit Root Problem}

To test the stationary assumption unit root, the correlogram and the graph of Autocorrelation and partial correlation from Stata show that LREM is nonstationary. But taking the first difference of the LREM and do the same process again the stationary nature of the variable is found. So it can be said that the variable LREM is I (1) i.e. integrated of order 1. The same process was performed for the other 4 variables and found that those variables are also I (1) in nature. The first difference of the variables LINFD, LINTRD and LGDPW are significant at $5 \%$ level so all the variables of the model are I (1).

Now to test the spurious relationship of the variables cointegration test is applied to observe whether the variables are spurious or not. Now if it is found that the variables are not spurious, 


\section{Macrothink}

it can be said that they are cointegrated, then we can apply usual OLS technique for the estimation of the model.

Table 1. Model summary

\begin{tabular}{llllll}
\hline Model & R & R-Square & Adjusted R Square & Standard Error Estimates & Durbin Watson \\
\hline 1 & 0.677 & 0.458 & 0.402 & 2.55224 & 2.151 \\
\hline
\end{tabular}

Source: Field work, 2013.

Table .1 explains various measures of model fitness as $\mathrm{R}^{2}$, Adjusted $\mathrm{R}^{2}$ and Durbin Watson $\mathrm{d}$ statistic for the detection of model specification error and autocorrelation. The co-efficient of determination $\mathrm{R}^{2}$ is an important measure of goodness of fit of fitted regression model that is it finds out how "well" the sample regression line fits the data.

More simply, it shows the proportion of variations in dependent variable due to all explanatory variables included in the model. Its value always lie between 0 and 1 , greater the value of $\mathrm{R}^{2}$ larger (closer to 1 ) the evidence of goodness of fits. In our study $\mathrm{R}^{2}=0.458$ which shows total variations in macroeconomic variables are due to all the explanatory variables like inflation, interest rates, GDP growth and internal remittances.

We used Durbin Watson d statistic to detect autocorrelation and any type of specification error in our regression model. A rule of thumb, if the value of Durbin-Watson is 2 in an application, than it can be believed that there is no autocorrelation, either positive or negative. Table 1shows that in our model DW is 2.151 so, using table values of DW it is observed that there is no autocorrelation or any type of model specification error.

Table 2. ANOVA

\begin{tabular}{llllll}
\hline Model & Sum of Squares & Degree of freedom & Mean of Square & F. Sign & \\
\hline 1 & 159.755 & 3 & 53.252 & 8.175 & 0.000 \\
& 188.904 & 29 & 6.514 & & \\
& 348.659 & 32 & & & \\
\hline
\end{tabular}

Source: Field work, 2013.

Table 2 gives ANOVA that explains total variations (TSS) in explained (ESS) and unexplained or residual (RSS) variations. In our study ESS is 16.765 which are $0.030 \%$ of total variations and this is variations in macroeconomic variables due to fluctuations in all explanatory variables.

The residual sum of square shows the variations in dependent variable that are not due to explanatory variables included in our model. RSS in our study is 543.490 indicates that there is 543.490 variations in inflation, interest rate and income of the consumer represented by 


\section{Macrothink}

GDP due to residuals which is total variations. The use of F-test statistic is made in order to examine the overall significance of the model.

Table 3. Evaluation of estimates

\begin{tabular}{llllll}
\hline $\begin{array}{l}\text { Variables } \\
\text { LGDPW }\end{array}$ & coefficient & Standard error & $\mathrm{T}$ & $\mathrm{P}>|\mathrm{t}|$ & Observation \\
\hline Constant & 9.725 & 2.574 & 3.777 & 0.001 & 33 \\
FD LINFD & -0.060 & 0.018 & -3.380 & 0.002 & 33 \\
LINTRDR & -0.98 & 0.047 & -2.085 & 0.040 & 33 \\
FDL REM & -0.003 & 0.035 & -0.080 & 0.937 & 33 \\
\hline
\end{tabular}

e (for cointergration test)

$\mathrm{F}-$ test $=8.175$

Prob $>\mathrm{F}=0.000$

$\mathrm{df}=32$

\section{Results and Discussions}

From the Table 1 above, we confirmed the study by Katseli and Glyson (1986) in Greece; internal remittances disclosed a negative relationship among inflation, interest rate, GDP growth rate and interest rate. Hence the conclusion that this results is the best representation of our expected model. We can clearly establish that all the other variables except internal remittances variable which is not significant, the rest are significant at $95 \%$ level. The superiority of the result can be seen by the following criteria. From the table, we have also seen that all the variables have negative correlation thus the dependent variable and the independent variables.

In comparism' with other studies, it was clear that this study confirmed by many other studies which shown the negative trend like the one in Ghana.

\subsection{Test for Cointegration}

Whether the nonstationary times series produces a spurious regression with another nonstationary time series, a cointegration test is necessary to check this relationship. Here it is used the Engle- Granger (EG) or Augmented Engle-Granger (AEG) test to see the relations. To perform this test one should first find out the residual of model and then check to see whether residual contains. In this paper, it was seen that the variables are cointegrated as the calculated value of the residual $\mathrm{e}$ is (showed in the above table). As the variables are cointegrated, OLS technique can be used to estimate the model.

\subsection{The Granger Causality Test}

To see the bilateral causality among the variables, we used granger causality test and for the multivariate model we used VAR model. After finding the Basic VAR it we tested and find that both LREM and LINFD do not Granger cause each other. On the other hand LINTRD 
and LGDPW Granger Causes the LREM but not opposite is not true. Again LTOT do not Granger causes LREM. So here it is found that there is one way causation that which is expected from the model after analysis the regression result.

Autocorrelation: There is no pure autocorrelation in the model.

From the Breusch -Godfrey (BG) test), it is seen that the Chi-square value is with $29 \mathrm{df}$.We see here the null hypothesis, $\mathrm{H} 0=$ there is no serial correlation. Now the critical Square value with $\mathrm{df}=32$ at $5 \%$ level is 2.86 . But the calculated value is only which is less. That means there is no pure autocorrelation.

Functional Form: The result of the functional form ( $F$ stat) is 8.175 . The $p$ value which is less than $10 \%$ level of significance is.

Normality: Distributing the error terms are clearly shown as normally distributed. The $p$ value of obtaining from the Chi-square distribution with $33 \mathrm{df}$ is about 32 which is quite high.

Heteroscedasticity: In Breusch-Pagan/Cook-Weisberg test for heteroskedasticity it is assumed the Null hypothesis that there is no heteroscedasticity in the model.

But the calculated Chi-square value is which is very high so we cannot reject the Null that there is no heteroscedasticity. It can be said that there is homoscedasticity or have constant variance.

Multicollinearity: From the pair correlation among the regressors it is observed that there is no multicollinearity. The pair wise correlations here are not above -0.003 , except LREM and LGDPW (-.0.079).

Overall Significance of the model: From the F statistics with df of numerator and the denominator A and B respectively, it is seen that the value of F-test is 8.175 which shows the significance of the model. As the $\mathrm{p}$ value of $\mathrm{F}$ statistics is very low i.e. very close to zero [0.000]. Therefore the model is a significant model.

\subsection{Forecasting}

From the study, remittance inflow in Ghana is not very quick to respond to changes in the domestic interest rate. As log-linear model is a constant elasticity model, the coefficients of the variables are constant throughout. In similar way, if the GDPW increases by $1 \%$, then remittance will decrease by $-0.003 \%$. This shows that remittance is not very responsive to the changes in GDP of the country. If all the regressors become zero then the remittance inflow will be negative, i.e. -9.725 . Of course the mechanical interpretation of the intercept may not make much economic sense. Since it is found that the results are according to the priori expectation, the model seems correct.

Internal remittances cannot be taken out from the model because of its unique role it plays the study hence it was not significant variable. 


\subsection{Data Source and Discussion}

Data were derived from secondary sources. Pools of data were extracted from publications of the State of the Ghanaian Economy, Ghana Government Budget and Economic Policy Statement for Various Years, Ghana Statistical Service Yearly Report, The world Economic out Look 2006-2009, ISSER and CEPA annual reports. The sample data contain all the six sectors in which government carried out expenditure. The sample data used cover the period 1980 to 2012; and the sectors covered are six in number namely: economic growth; internal remittances, inflation interest rates. The Regression Analysis was run by Econometric Stata.

\section{Conclusion}

The aim of the study was to investigate whether the macroeconomic factors of Ghana can affect positively the internal remittance inflow into the rural Ghana. Now the result seems to conclude that macroeconomic factors of the Ghana have significant impact on remittances except remittance variable which showed otherwise. Remittance is a main source of development in rural areas in Ghana and also a source of livelihood strategy for many households in Ghana and therefore should not be understudied. The contribution of migrant workers in Ghana to development of Ghanaian economy is significant.

\section{Policy Recommendations}

The main recommendation for this study is that there should be a formal way for migrants to send their remittances home without fear of cheating by relatives and friends. At macro level, we can minimize the level of internal migration and encourage even development in every area of Ghana. This will reduce inequalities that exist in some parts of the country in resource allocation and views every district as important contributing to overall development of Ghana. Ghana government can make it a policy for every region to submit data on macroeconomic variables to the statistical service as quarterly or monthly requirements and how it will influence resource allocation.

\section{References}

Elbadawi, I. A., \& Rocha, R. (1992). Determinants of Expatriate Workers' Remittances in North Africa and Europe. World Bank Working Paper Series 1038.

El-Sakka, M., \& MaNabb, R. (1999). The Macroeconomic Determinants of Migrant Remittances. World Development, $\quad 27, \quad$ 1493-1502. http://dx.doi.org/10.1016/S0305-750X(99)00067-4

Faini, R. (1994), Workers Remittances and the Real Exchange Rate: A Quantitative Framework. Journal of Population Economics, 7, 235-245. http://dx.doi.org/10.1007/BF00173621

Glytsos, N. (1997). Remitting Behaviour of "Temporary" and "Permanent" Migrants: The Case of Greeks in Germany and Australia. Labour, 11, 409-435. http://dx.doi.org/10.1111/1467-9914.00043 


\section{Macrothink}

International Journal of Social Science Research

ISSN 2327-5510 2014, Vol. 2, No. 2

Higgins, M., Hysenbegasi, A., \& Pozo, S. (2004). Exchange-rate uncertainty and workers' remittances. Applied Financial Economics, 14, 403-411. http://dx.doi.org/10.1080/09603100410001673630

Katseli, L., \& Glytsos, N. (1986). Theoretical and Empirical Determinamts of International Labour Mobility: A Greek-German Perspective. Centre for Economic Policy Research Working Paper 148.

Lucas, R., \& Stark, O. (1985). Motivations to Remit: Evidence from Botswana. The Journal of Political Economy, 93, 901-918. http://dx.doi.org/10.1086/261341

Ratha, D. (2003). Worker's Remittances: An Important and Stable Source of External Development Finance in: Global Development Finance, pp.157-172 (World Bank).

Straubhaar, T. (1986). The Determinants of Workers' Remittances: The Case of Turkey. Weltwirtschaftliches Archiv, 122, 728-740. http://dx.doi.org/10.1007/BF02707858

Swamy, G. (1981). International Migrant Workers' Remittances: Issues and Prospects. World Bank Staff Working Paper 481.

Taylor, J. (2004). Remittance Corridors and Economic Development: A Progress Report on a Bush Administration Initiative in: Payments in the Americas Conference (Federal Reserve Bank of Atlanta).

\section{Copyright Disclaimer}

Copyright for this article is retained by the author(s), with first publication rights granted to the journal.

This is an open-access article distributed under the terms and conditions of the Creative Commons Attribution license (http://creativecommons.org/licenses/by/3.0/). 